\title{
Analysis Neotectonic Activities in Khafr Basin
}

\author{
Ahmad Ansari Lari' ${ }^{1}$, Maryam Ansari², Soraya Ansari ${ }^{3}$ \\ ${ }^{1}$ Larestan Azad University, Larestan, Iran \\ ${ }^{2}$ Tabriz University, Tabriz, Iran \\ ${ }^{3}$ Hygiene and Family Health of Gerash University, Gerash, Iran \\ Email:ansarl_ul@yahoo.com, ansarimaryam149@gmail.com,soraya1.ansari@yahoo.com
}

Received 19 May 2016; accepted 25 June 2016; published 28 June 2016

Copyright (C) 2016 by authors and Scientific Research Publishing Inc.

This work is licensed under the Creative Commons Attribution International License (CC BY).

http://creativecommons.org/licenses/by/4.0/

(c) (i) Open Access

\begin{abstract}
As Iran is located on one of the two earthquake-prone belts in the world, and existence of faults and earthquakes is normal in Iran tableland. The main reason of earthquake is Neotectonic movements which can be effective in other natural disasters such as range movements. Due to the severe shortage of historical and seismic data and device in different parts of the world, particularly Iran, need for introducing more researchers and planners of Iran to tectonics and active tectonic areas is more visible. This study is an investigation of Neotectonic activities in Khafr basin area, Fars province. To achieve the aims of this study morphometric parameters were used. Investigations showed that severity and role of tectonic activities in different parts of the basin is different, results of geomorphic and tectonic assessments indicate these differences. Stream lengthgradient index $(S L)$ on the main stream is inactive and sub streams are semi active, the ratio of the basin $(B S)$ is 2.27 , drainage basin asymmetry index $(A F)$ is in semi active class, the ratio of width to depth of Valley $(V F)$ shows 0.78 . Indicators mentioned are in class 3 based on Iat classification, that represents tectonic activity in the area is average. Other indicators are indicative of active tectonic in the basin such as drainage density index $(D)$ with high density, river sinuosity $(S) 1.25$, reverse topography symmetry Factor $(T) 0.3$. Generally it can be considered as moderately active region in terms of tectonic activities.
\end{abstract}

\section{Keywords}

Neotectonic, Geomorphic Indicators, Drainage Density Index, Basin of Khafr

\section{Introduction}

One of the issues in tectonic geomorphology is Earthquake risk assessment in specific areas through the study of 
the problems associated with active faults and determination of seismic zone status in upper Pleistocene and Holocene [1]. The ongoing competition between tectonic processes that tend to create topography surface processes that tend to erode and disintegrate them represents a tectonic geomorphology [2], Neotectonic studies phenomena including all the factors, processes and practices arising from new activities of the Earth (on a geological scale) and forms created by these activities, moreover, by this type of investigation, relatively stable and tectonically inactive regions can be identified. This relatively new branch of applied geomorphology can be used in solving the problems caused by tectonic geomorphology where landforms of roughness and evolution of landscapes caused by new tectonic activities are discussed [1].

As Iran is located on one of the two earthquake-prone belts in the world and a lot of faults, earthquake in Iran tableland is normal. The main cause of earthquakes is Neotectonic movements which can be effective in other natural disasters such as range movements [3]. Due to the severe shortage of historical and seismic data and device in different parts of the world, particularly Iran, need for introducing more researchers and planners of Iran to tectonics and active tectonic areas is more visible. Qualitative measurement is not responsible for evaluating these activities. Quantitative and numeric assessment make it possible for geomorphologists to evaluate different landforms truly and tangibly; some tools are introduces for this aim, morphometric indexes are among them.

Assessment of research resources is one of the important tasks in any research work. Regarding tectonic activities using geomorphic indexes, a lot of studies have been conducted in Iran and other countries such as Ghanbari [4] who investigated earthquakes in relation to active faults, especially quaternary faults in Azerbaijan using mathematical relationship on fault of Tabriz and Salmas. Madadi, Rezayi Moghaddam and Rajayi [5] analyzed tectonic activities in northwestern slopes of Talesh using geomorphological methods and for this purpose, geomorphic indexes are used such as Mountain Front, ratio of valley width to its height, river gradient index and etc. Mokhtari [1] studied tectonic and expanding holes of Marand from sedimentary tectonics the perspective. In his study, role of tectonic factors in creating tectonic holes in Marand is explained by analysis of data related to sedimentary morphological factors. Roostae and Nayeri [6] analyzed effect of lithology and tectonic on longitudinal side view of Mahabad River and for this purpose, Geomorphic indexes were used such as SL index, standardized index SL/K, drainage density index, and concavity index.

Bull [7] studied Neotectonic activities and distinguished active regions and inactive regions by sinuosity of Mountain Front Methods (Smf), ratio of valley width to its height (Vf), and Drainage basin shape (Bs). Keller, Larry and Tierney [8] presented geomorphological indexes related to lateral growth of earth folds. There are six geomorphological indexes including: drainage density, cutting head of folds, reduction in topographic height of fold head in side view, reduction in side slope of the fold, deformation of young alluvial deposits, and growth of certain drainage patterns. Jamieson, Sinalair, Kirestein and Purves [9] in their article investigated the effect of tectonic factors on split Ratio, drainage density, hypsometric integral of rivers network in Himalayas in northern India. Singh and Jain [10] conducted a research entitled tectonic pressure on development front plates in edges of the stream in North West of Himalayas in India. Reyaz Ahmad, Shakil Ahmad, Rakesh and Ishtiaq [11] studied geomorphologic tectonics of Karwa basin in the valley of Kashmir using geomorphic indexes such as SL, Smf, RC, Rb, D and AF; they found that there is a high degree of active tectonics in the area.

Khafr basin is a narrow basin located between two mountain ranges namely Simakan and Meymand on one side, and White Mountains (Goshtasb) on the other side and Ghareaghaj river runs through it. Existence of this river caused a desirable climate a blooming environment in this area. Knowledge of local neotectonic conditions can be effective largely from earthquakes' life and property damages and damages caused by natural disasters such as range motions.

Therefore, aims of this study are tectonic activity evaluation and investigation of tectonic activities in Khafr basin with regard to the validity geomorphic indexes through quantitative approach.

\section{Studied Area}

Khafr basin geographically is located is located on $52^{\circ} 42^{\prime} 43^{\prime \prime}$ to $53^{\circ} 30^{\prime} 3$ " longitudinal east and $28^{\circ} 5^{\prime} 56^{\prime \prime}$ to $29^{\circ} 8^{\prime} 20^{\prime \prime}$ northern latitude. Khafr basin in Jahrom city, Iran, is about 1182.5 square kilometers and one of the most populous and important part of Jahrom city. The maximum height of the basin is 3163 meters, its minimum height is 1165 meters, and its average height is 1735 meters. The main hydrographic network and the only major flows within the Ghareaghaj River is approximately $59 \mathrm{~km}$ (Figure 1). 


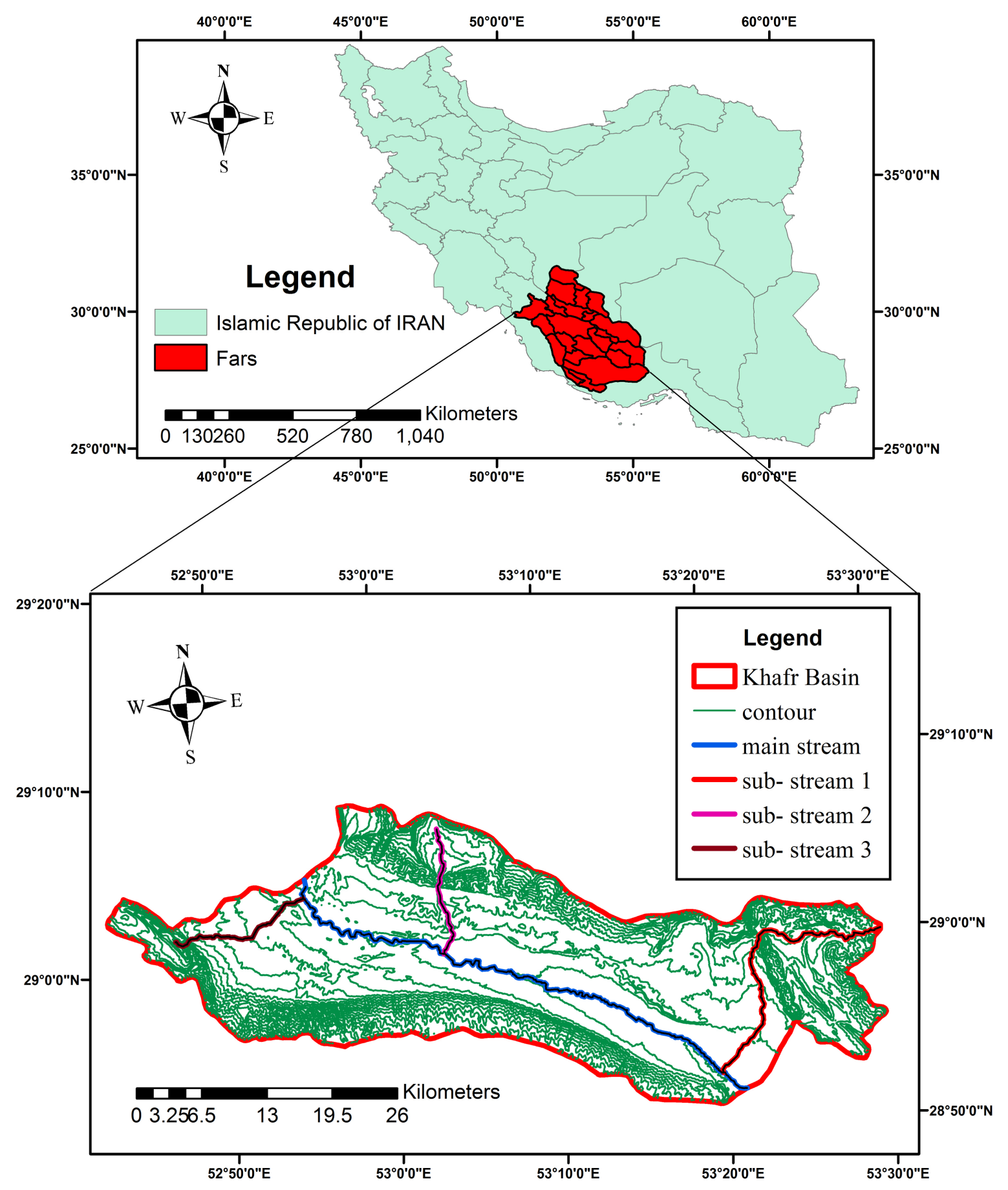

Figure 1. Location of the studied area in a map of Iran and Fars.

\section{Geological of Studied Area}

Investigation of geological map of 1:250,000 Shiraz and Jahrom showed that the case area is consisted of several formations that are different in terms of resistance, these formations include: Bangestan (Bgp) is often of limestone, crack systems and karst phenomena usually are developed in them. Tarbur (Ktb): This formation is related to Upper Cretaceous, mainly is composed of massive reef limestone and its color is cream-colored, Gurpi (Gu): In the cutting of this formation is seen $320 \mathrm{~m}$ gray-blue marl and shale and secondarily layers of clay li- 
mestone, this formation has little resistance against erosion and has created the gentle topography. Pabdeh (Pd) This formation is related to Eocene and consists of clay sediment in terms of lithology. Sachun (Pesc) Mainly includes white to gray gypsum, yellow dolomites, silty lime stones and red marl. The upper part of this formation is composed of massive and marly gypsum with dolomite. Asmari Jahrom (OME as ja): Jahrom formation mainly composed of fossiliferous limestones with good layering and sometimes with layers of marly limestone, Asmari formation is mainly consists of cream to brown resistant limestone with shale layers. Age of this formation is considered Oligocene to lower Miocene. Razak (Mrz) is related to lower Miocene and is composed of red, green and gray Marly rocks, in some cases gypsum can be found. Aghajari (Mpl aj) Limestone it begins with brown to gray sandstone layers and a thickness of 2 to 5 meter , and continues with a thick layer of red marl and thin layers of sandstone and silt, sandstones of this formation are usually highlight mode but marl and silt have been deep erosion. Bakhtiari (Pl bk): age of Bakhtiari formation is the late Pliocene to early Pleistocene that is composed of conglomerate and sandy marly conglomerate and current alluvium. Sediments of Quaternary exist on the surface and different heights of each type of rock from any era and created several low steep lands which are separated by rough stone heights and formed big and small fields. Most residential and agricultural areas of Khafr are built on current alluvium which encompasses approximately $372.5 \mathrm{~km}^{2}$ that is $32 \%$ of Khafr section (Figure 2).

\section{Methodology and Materials}

In this study aerial photos with scale of 1/55,000, satellite images, geological maps 1/250,000 of Shiraz and Jahrom sheets, moreover Digital Elevation Model (DEM) is used to analysis and extraction of tectonic activity

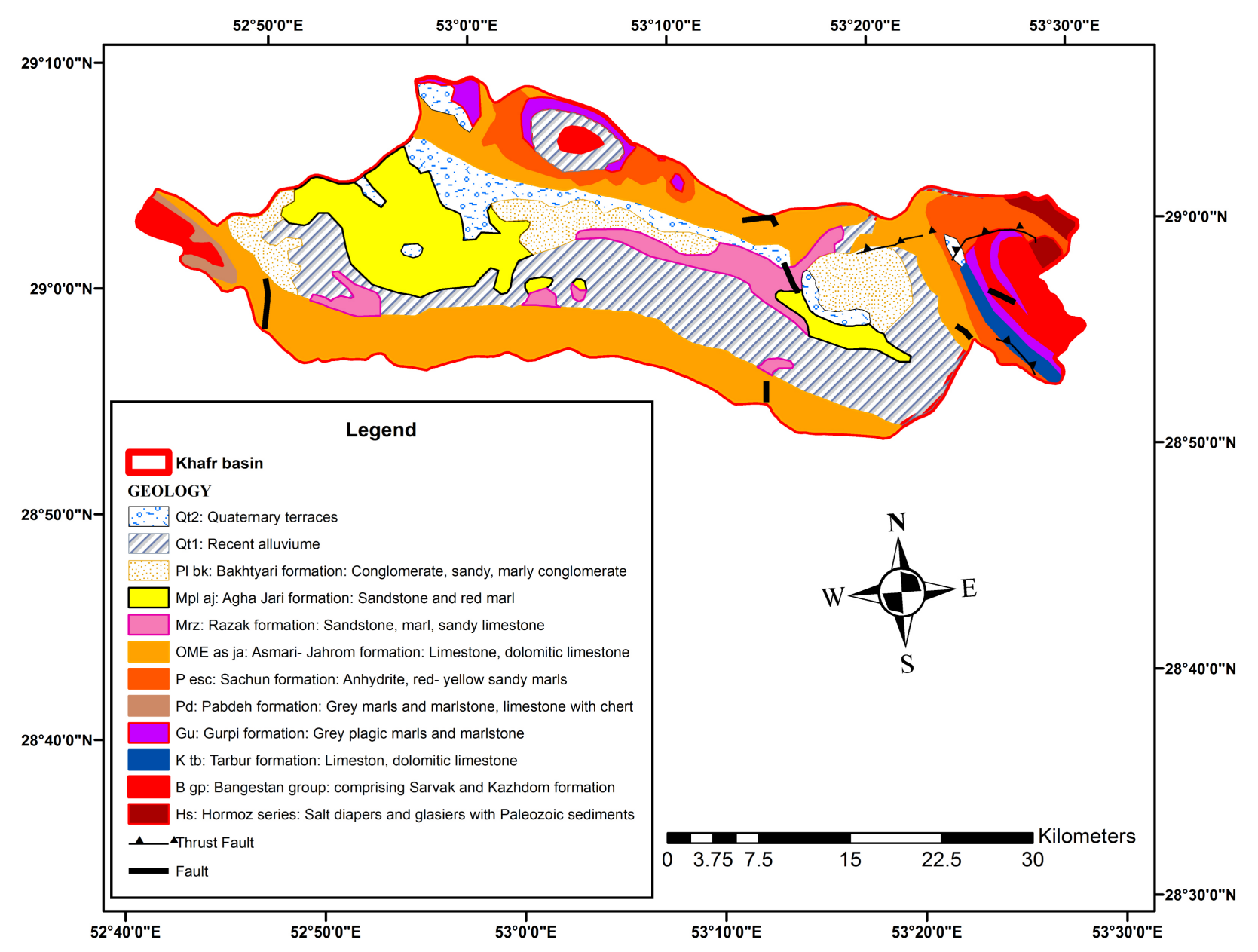

Figure 2. Geological map of studied area. 
indicators and drainage networks. Arc GIs 10.2, Excel and Global mapper soft wares were used to prepare different maps, finding required data and data analysis.

In this study stream length-gradient Index (SL), drainage basin asymmetry ( Asymmetric factor) (AF), Index of drainage basin shape(BS), ratio of valley floor width to valley height index (VF), drain density index(D), river sinuosity index (S) and transverse topographic symmetry index $(\mathrm{T})$ is used to investigate the effect of tectonic activities on valleys and rivers and as well as calculating the required indexes in Khafr basin, main stream, and subsidiary stream (By Strahler method).

\subsection{Stream Length-Gradient Index (SL)}

It is one of indexes for tectonic force assessment which is stated by the following correlation:

$$
S L=(\Delta H / \Delta L) L
$$

$S L=$ Stream length gradient

$\Delta H / \Delta L=$ Stream slope or gradient of a sheet

$\Delta H=$ height difference of the case sheet

$\Delta L=$ branch length of the case sheet

$L=$ length of the river from central point of the measured sheet to the headstream [12].

Theses parameters are measured by topographic maps and digital elevation model (DEM). The values of SL index were classified into three categories: 1 (SL $\geq 500), 2$ (300 $\leq \mathrm{SL}<500)$ and $3(\mathrm{SL}<300)$ [13].

\subsection{Ratio of the Basin Form Index (BS)}

Tectonically active basins have elongated shapes. Form of the basin gradually becomes circular by a pause in amount of uplift over time [20]. This index is divided into three classes of activities: BS $>4$ active, $3<$ BS $<4$ semi-active and BS $<3$ inactive [13] which is computed by Equation (2):

$$
B S=B i / B w
$$

$B i=$ the basin longitude: the distance between lowest height of the basin and its farthest point

$B w=$ width of the basin: the widest part of it

\subsection{Drainage Basin Asymmetry Index (AF)}

Asymmetry index for determining the tectonic tilting of the drainage basins and larger areas are as follows in Equation (3) [14]:

$$
A F=100(A r / A t)
$$

Ar: right area of the river, At: total area of the drainage basin.

Af-50 $<7$ inactive, $15>$ Af-50 $>7$ semi-active and Af-50 $>15$ is placed in active class.

\subsection{Drainage Density Index (D)}

Drainage density is the ratio length of the stream to area of the area as follows (Equation (4)):

$$
D=L / A
$$

$D=$ Drainage density index

$L=$ total length of streams in $\mathrm{km}$

$A=$ total area in square kilometers

This index indicates rupture of topography which can be related to tectonic, type of bedrock and amount of rainfall [15]

Low density is between 0.6 and 0.6 , average between 0.6 and 0.9 , high if it is above 0.9 [16].

\subsection{The Ratio of Width to Depth of Valley (VF)}

This index is calculated by Equation (5): 


$$
V f-2 V f w /[(E L D-E s c)+(E r d-E s c)]
$$

$V f w=$ width of the valley floor

Erd = average height of water dividing line on left and right side of valley

$E s C=$ average height of the valley floor from the open waters [17]

This index reflects the difference between V-shaped and U-shaped valleys, this means that in V-shaped morphology of the valley $V f w$ is closer to zero which indicates destruction and that in U-shaped morphology of the valley, amount of $V f w$ increase which indicates widening and leveling of valley and low intensity of tectonic processes and sustainability of valley [18]. Based on Hamdooni's classification [13] Vf less than 0.5 is active, between 0.5 to 1 is semi-active and greater than 1 is inactive.

In this study, to calculate $V f$ index, Global mapper software was used by eight cross-section on the main stream and sub-streams in the highlands of 1370.82, 1560.77, 1661.84, 1726.64, 1857.26, 2103.88, 2295.35 and 2338 that show the valley floor heights, they are drawn perpendicular to the stream, then the necessary calculations have been performed on them.

\subsection{Sinuosity of River $(S)$}

Sinuosity index is calculated by Equation (6):

$$
S=C / V
$$

$S=$ Sinusitis or the twists and turns of the river

$C=$ length of the river

$V=$ length of the valley [14].

Rivers that have a lot of twists and turns are very close to equilibrium, while the direct river route represents younger and existence of neotectonic activities in the area. The high values of this index shows that the river is closer to equilibrium while, low value of this index indicate tectonic activity in the case area [19].

\subsection{Transverse Topographic Symmetry Factor ( $T$ )}

Index $\mathrm{T}$ is a vector with a certain orientation and different values between 0 - 1 . In perfectly symmetrical Basins, the value of this index is zero. By reducing the symmetry of the basin, $\mathrm{T}$ index increases and gets closer to 1 which is computed by Equation (7):

$$
T=D a / D d
$$

$D a=$ the distance between Midfielder of drainage basin and main river route

$D d=$ the distance between Midfielder of drainage basin and Water dividing line [14].

\subsection{Active Tectonics Index (Iat)}

After calculating the geomorphic indices in the study area is estimated tectonic activities in the area using Iat index. Iat index is achieved from the average of different geomorphic indicator classes according to the following equation:

$$
\text { Iat }=S / N
$$

$S$ : Total classes geomorphic indicators that is calculated

$N$ : Number of indicators

The values of the index were divided into four classes to define the degree of active tectonics: 1 -very high

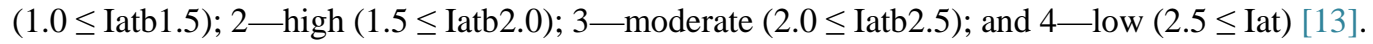

\section{Discussion}

To calculate the amount of longitudinal slope of Khafr basin in three altitude on the main stream, 4 height areas were considered on sub-stream, and longitudinal side views were drawn (Figure 3) and SL values for each of them were calculated and the results are given in tables (Tables 1-4).

According to results of SL index value, the main stream can be classified according to Hamadooni [13] that is 

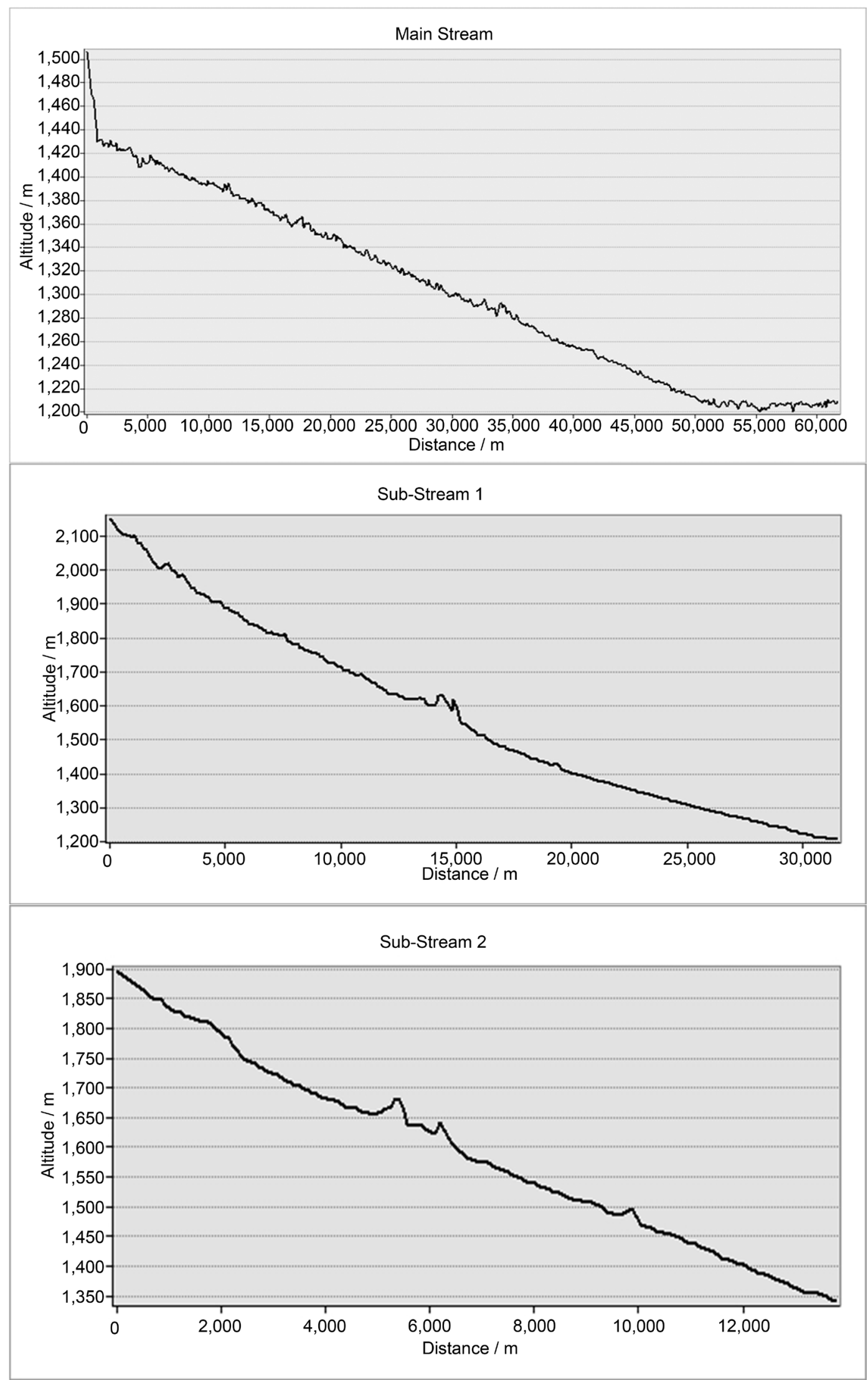


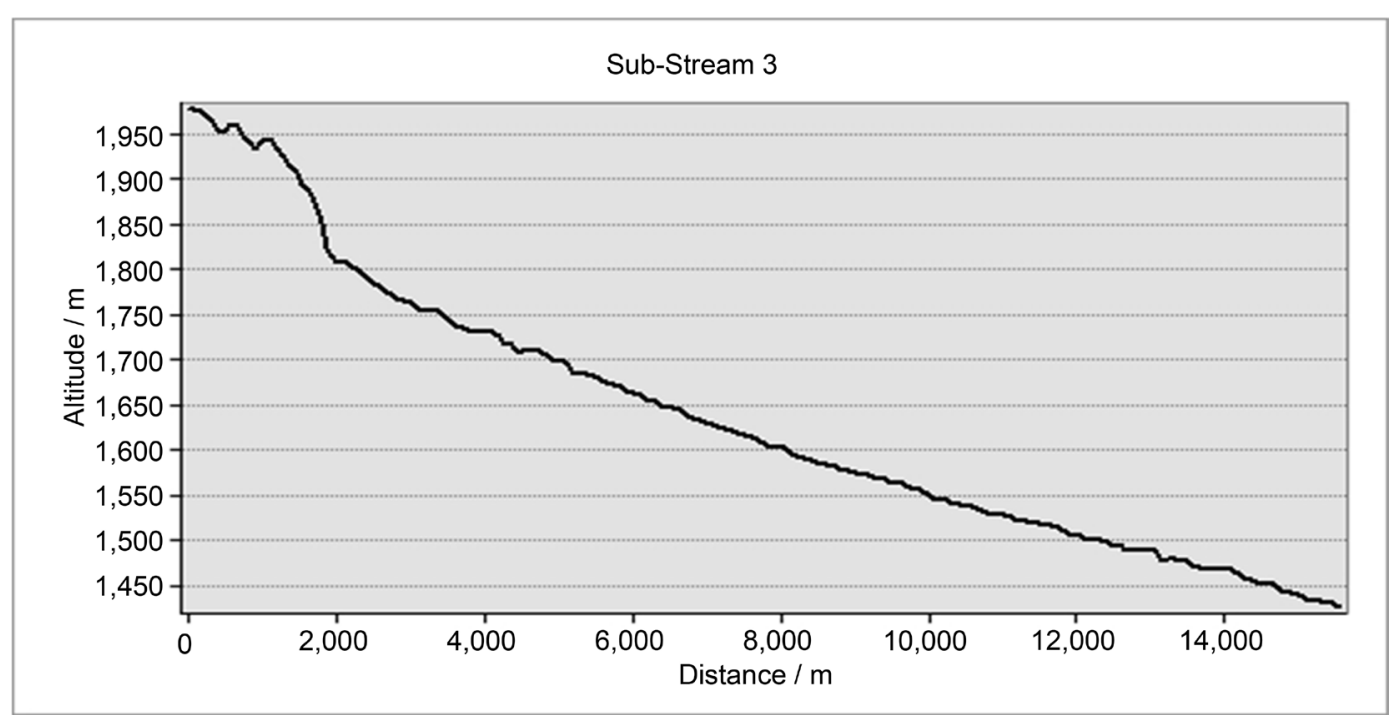

Figure 3. Longitudinal profiles of SL.

Table 1. Values of the SL classes (stream-gradient index) in 3 elevation ranges in the main stream.

\begin{tabular}{cccccc}
\hline Class of $S L$ & Values $(\mathrm{m}) S L$ & $L$ & $L \Delta$ & $H \Delta$ & Elevation ranges \\
\hline 3 & 156.8 & $44,553.81$ & $28,416.26$ & 100 & $1200-1300$ \\
3 & 89.54 & $19,472.48$ & $21,746.41$ & 100 & $1300-1400$ \\
3 & 59.36 & 4668 & 7862.58 & 100 & $1400-1500$ \\
\hline
\end{tabular}

$\Sigma: 101.8$.

Table 2. Values of the SL classes (stream-gradient index) in 4 elevation ranges in Sub-stream.

\begin{tabular}{cccccc}
\hline Class of SL & Values $(\mathrm{m}) \mathrm{SL}$ & $L$ & $L \Delta$ & $H \Delta$ & Elevation ranges \\
\hline 1 & 901.7 & $20,880.26$ & 4631.49 & 200 & $1300-1500$ \\
2 & 459.11 & $13,342.6$ & 5812.349 & 200 & $1500-1700$ \\
3 & 258.81 & 7527.83 & 5817.2 & 200 & $1700-1900$ \\
3 & 138.6 & 2683.175 & 3872.11 & 200 & $1900-2100$ \\
\hline
\end{tabular}

$\Sigma: 436.555$.

Table 3. Values of the $S L$ classes (stream-gradient index in 4 elevation ranges in Sub-stream 2.

\begin{tabular}{cccccc}
\hline Class of $S L$ & Values $(\mathrm{m}) S L$ & $L$ & $L \Delta$ & $H \Delta$ & Elevation ranges \\
\hline 2 & 441.2 & $12,025.05$ & 2725.74 & 100 & $1400-1500$ \\
2 & 326.98 & 9248.03 & 2828.3 & 100 & $1500-1600$ \\
3 & 225.530 & 6412.28 & 2843.2 & 100 & $1600-1700$ \\
3 & 210.5 & 4032.8 & 1915.77 & 100 & $1700-1800$ \\
\hline
\end{tabular}

$\Sigma: 301.0525$.

tectonic tranquility in Class 3, sub-streams in Class 2 which means a moderate tectonic activity. In general, sub-streams at lower altitudes have more tectonic activity (Figure 4).

The shape of the basin (BS), in Khafr basin was 2.7 (Table 5) which indicated inactivity of this basin (Figure 4).

According to calculations (Table 6) AF index in Khafr basin is 57.75 that if it is deduced from 50, it will be is 
Table 4. Values of the $S L$ classes (stream-gradient index) in 4 elevation ranges in Sub-stream 3.

\begin{tabular}{cccccc}
\hline Class of SL & Values $(\mathrm{m}) S L$ & $L$ & $L \Delta$ & $H \Delta$ & Elevation ranges \\
\hline 2 & 325.5 & $13,420.7$ & 3074.91 & 100 & $1500-1600$ \\
2 & 305.33 & 9760.7 & 3196.77 & 100 & $1600-1700$ \\
3 & 248.95 & 6797.18 & 2730.24 & 100 & $1700-1800$ \\
1 & 802.6 & 5113.52 & 637.1 & 100 & $1800-1900$ \\
\hline
\end{tabular}

$\Sigma: 420.595$.

Table 5. Value and tectonic activity class of BS index in Khafr basin.

\begin{tabular}{cccc}
\hline Class of $B S$ & $B S$ & $B W(\mathrm{KM})$ & $B(\mathrm{KM})$ \\
\hline 3 & 2.7 & 24.03 & 65 \\
\hline
\end{tabular}

Table 6. Value and tectonic activity class of AF index in Khafr basin.

\begin{tabular}{cccc}
\hline Class of $A F$ & $A F$ & $(A t) \mathrm{km}^{2}$ & $(A r) \mathrm{km}^{2}$ \\
\hline 2 & 57.75 & 1182.34 & 682.79
\end{tabular}

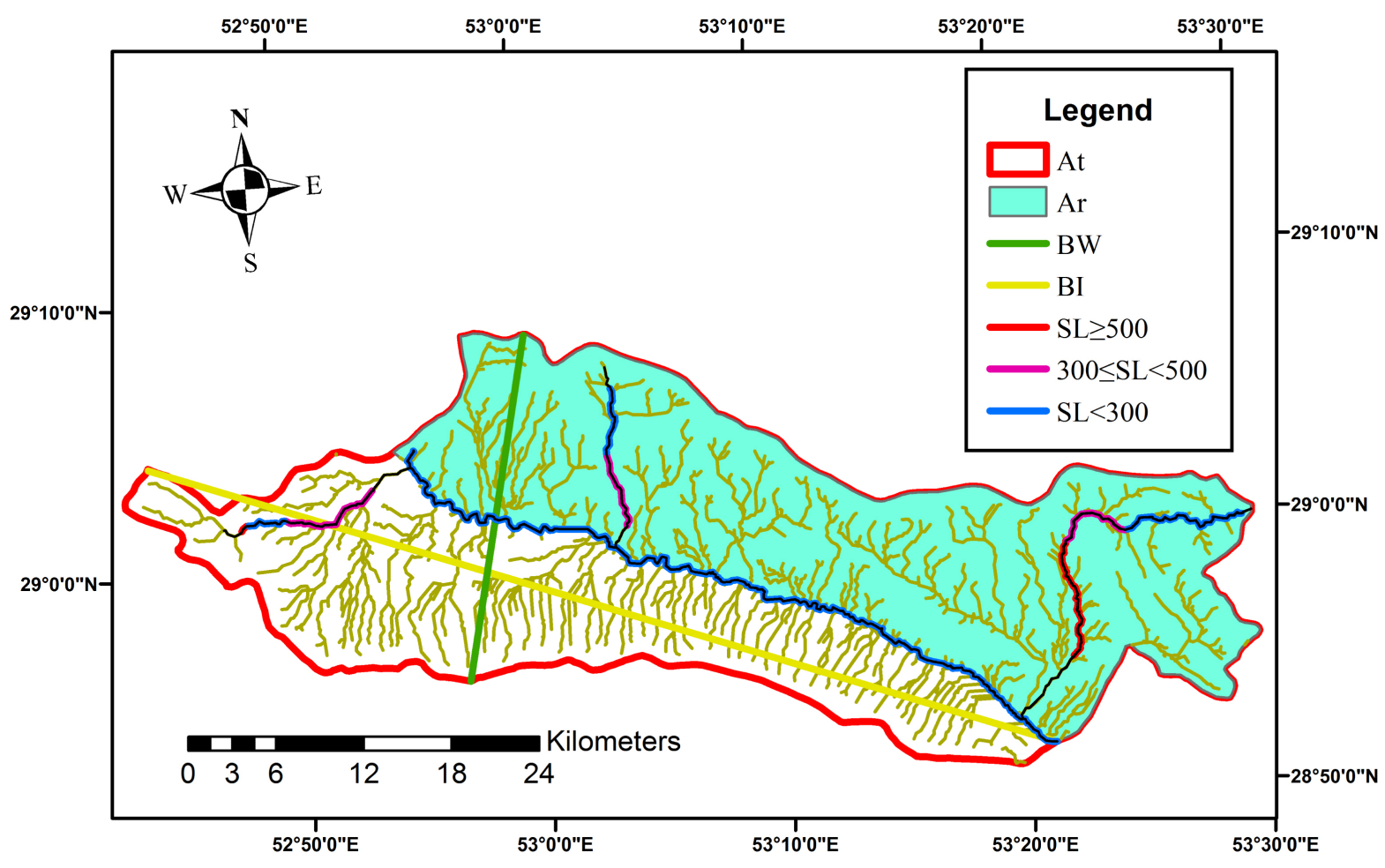

Figure 4. SL, AF, BS indexes along the drainage network.

equal to 7.75 that represents a tectonic function on the right bank of the main stream as well as greater length of sub-drainages on this side and it is classified in class 2 in terms of activities which shows a semi-active tectonic in the area (Figure 4).

To calculate $V f$ index, was used by eight cross-section on the main stream and sub-streams in that show the valley floor heights, they are drawn perpendicular to the stream, then the necessary calculations have been performed on them (Table 7). Based on the results, dominant tectonic activity in the area is active and semi-active. This indicates that tectonic activities did not let erosion to happen in the rivers of the region. 
Regarding the fact that tectonic activity is directly related to increased $V f$ index from upstream to downstream. By taking this index into account, tectonic activity is active in heights; in other parts of the basin tectonic activity is semi-active which confirms Hamadooni's classification, so according to this classification, the case basin is semi-active in terms of tectonic activity. Due to resistant lithological units in upstream, V-shaped valleys are often observed (Figure 5). According to Iat index, Indicators mentioned ( $S L, A f, V f, B s$ ) are in class 3, that represents tectonic activity in the area is average (Table 8).

In this study, Khafr basin is divided into two ranges: northeast and southwest. Based on ranking the length of sub-streams were computed for each range separately and ultimately for the entire basin. High level of index reflects more tectonic activity. The following results were found: for the northeast (1.32), the Southwest (1.4) and the whole basin (1.3) (Table 9 and Table 10).

According to the index, the case basin in both the North East and South West ranges and in whole, have a high drainage density that is indicates an active tectonic in the area (Figure 4).

To estimate the required data for $\mathrm{T}$ index in the case area, values of $D a$ and $D d$ were calculated in 10 separate sections and the results are presented in Table 11.

Given that the index value is zero which represents a symmetric basin and the results of the calculation is greater than zero, asymmetry in the basin proven, so it can be stated that the case area is tectonically semi-active.

Other indexes used to assess tectonic activities in Khafr basin, the sinuosity index of main stream. Thus, according to the obtained value from this index it can be claimed that the case area tectonically is active and did not reached equilibrium (Table 12).

Table 7. Values of the $V F$ classes in Khafr basin.

\begin{tabular}{ccccccc}
\hline Class of $V F$ & $V f$ & Erd & Eld & ESC & Vfw & $\begin{array}{c}\text { latitudinal profile } \\
\text { no. }\end{array}$ \\
\hline 1 & 0.48 & 1451.77 & 1449.52 & 1370.82 & 38.55 & 1 \\
2 & 0.92 & 1630.21 & 1637.21 & 1560.77 & 67.3 & 2 \\
3 & 2.6 & 1862.63 & 1842.57 & 1661.84 & 506 & 3 \\
2 & 0.63 & 1971.5 & 2001.15 & 1726.64 & 165.5 & 4 \\
2 & 0.67 & 2040.18 & 1986.46 & 1857.26 & 105.9 & 5 \\
1 & 0.23 & 2453.26 & 2466.81 & 2103.88 & 82.4 & 6 \\
1 & 0.38 & 2491.17 & 2511.88 & 2295.35 & 78.7 & 7 \\
\hline
\end{tabular}

$\Sigma: 0.78$.

Table 8. Classification of geomorphic indicators according to Iat index.

\begin{tabular}{ccccccc}
\hline \multicolumn{4}{c}{ Class of indicators } & & \multirow{2}{*}{$S / n$} & Class of Iat \\
\cline { 1 - 3 } & $A f$ & $V f$ & $B s$ & 2.25 & 3 \\
\hline
\end{tabular}

Table 9. Length of streams on the slopes of basin $(\mathrm{Km})$ in Khafr basin.

\begin{tabular}{cccc}
\hline Total & Southwest & Northeast & Slope \\
\hline 849.025 & 418.625 & 430.40 & 1 \\
419.8 & 184.651 & 235.151 & 2 \\
142.35 & 49.7571 & 92.9 & 3 \\
61.46 & 7.167 & 54.3 & 4 \\
62.8 & 39.791 & 23.009 & 5 \\
3.11 & 1.09 & 2.02 & 6 \\
1538.5 & 700.781 & 837.78 & Total \\
\hline
\end{tabular}




\section{A. A. Lari et al.}

Table 10. Drain density $(D)$ in Khafr basin.

\begin{tabular}{ccccc}
\hline Class of $D$ & Drain density $(\mathrm{km})$ & Area $\left(\mathrm{km}^{2}\right)$ & Length of $(\mathrm{km})$ streams & Slope \\
\hline 3 & 1.23 & 682.79 & 837.78 & Northeast \\
3 & 1.4 & 499.48 & 700.781 & Southwest \\
3 & 1.3 & 1182.35 & 1538.5 & Total \\
\hline
\end{tabular}

Table 11. Values of the $T$ index in Khafr basin.

\begin{tabular}{cccc}
\hline$T$ & $D d$ & $D a$ & Path no. \\
\hline 0.19 & 10.21 & 1.94 & 1 \\
0.24 & 10.152 & 2.44 & 2 \\
0.13 & 11.41 & 1.454 & 4 \\
0.22 & 10.78 & 2.42 & 5 \\
0.30 & 8.6 & 2.57 & 6 \\
0.33 & 7.1 & 2.345 & 7 \\
0.44 & 5.72 & 2.506 & 3
\end{tabular}

$\Sigma: 0.3$.

Table 12. Values of the $S$ index in Khafr basin.

\begin{tabular}{ccc}
\hline$S$ & $V$ & $C$ \\
\hline 1.25 & 49.48 & 61.68 \\
\hline
\end{tabular}

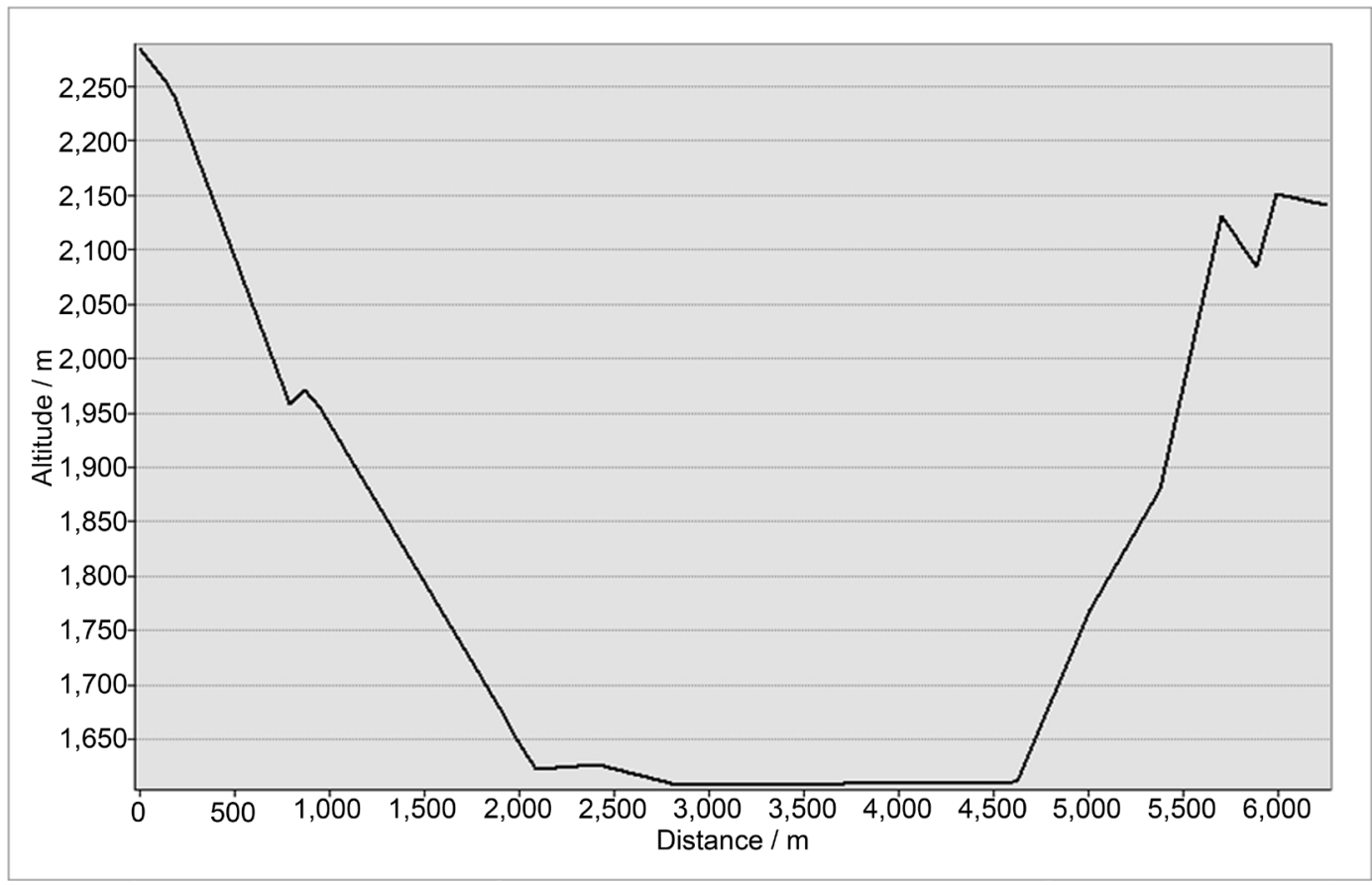



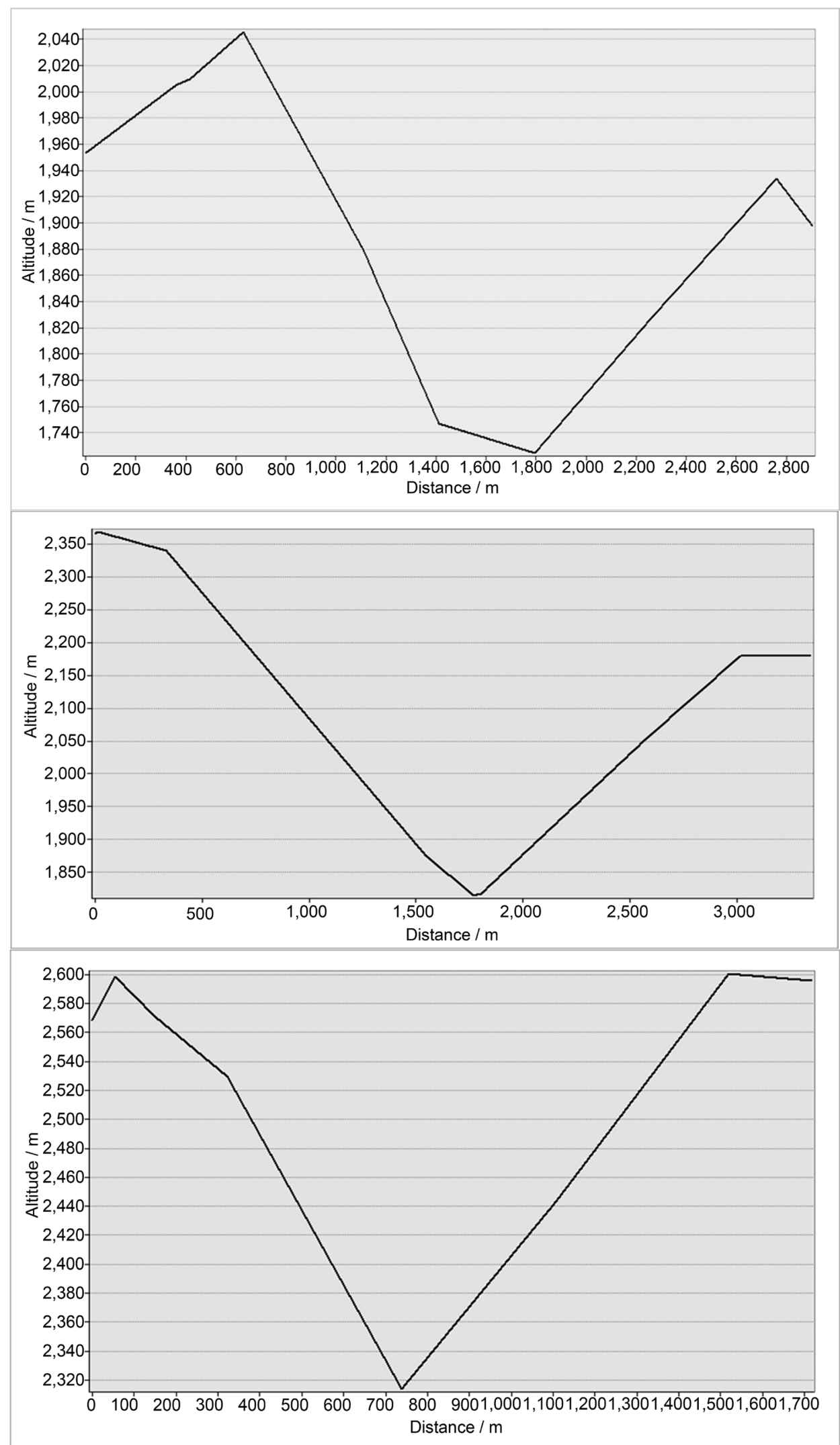

Figure 5. Latitudinal profiles to calculate VF index. 


\section{Conclusions}

In this study, based on geomorphic indexes the roles of tectonic activities in Khafr basin area were investigated. With regard to the value of SL index, main stream is in Class 3 that is tectonic tranquility, sub-streams are in class 2 with the moderate tectonic activity. Generally, sub-streams at lower altitudes are tectonically more activity. that reflects the asymmetry of; according to calculations of AF index, tectonic in the case area is semi-active, and tectonic activity is much more on the right bank compared to the left side of the main stream which indicates longer sub-drainage on this side. The shape of the basin (BS) in the case area was 2.7 that proves inactivity of the basin. VF index is measured for the main stream and 3 sub-stream in various locations. Based on the results, dominant tectonic activity in the area is active and semi-active. Indicators mentioned are in class 3 based on Iat classification, that represents tectonic activity in the area is average

To calculations of drain density index, length of Khafr drainage basin in the northeast and southwest ranges was calculated separately and totally. Based on the results of investigations the northeast (1.23), the Southwest (1.4) and the whole basin (1.3) were found which indicates the amount of high-density and therefore high tectonic activity. To compute $\mathrm{T}$ index in the case area, 10 separate sections were measured and the results show that the case area is semi-active tectonically. Besides, based on the sinuosity index of main stream it can be claimed that the case area tectonically is active and did not reached equilibrium.

Generally, intensity and role of tectonic activity in various parts of the basin is different, the results of geomorphic indexes and tectonic evaluation prove these differences. Finally, the area can be considered as a moderately active region in terms of tectonic activity.

\section{References}

[1] Mokhtari, D. (2007) Analysis of the Tectonic-Sedimentary of Marand Tectonical and Expanding Hole. Journal of Geographical Studies, 60, 129-146. http://www.magiran.com/view.asp?Type=pdf\&ID=475632\&l=fa

[2] Rezzai Moghaddam, M.H., Kheiri Zadeh, M. and Sarafroozeh, S. (2014) Assessment of Active Tectonics in South Slope of Misho Dagh. Quantitative Geomorphological Researches, 3, 141-158. http://www.geomorphologyjournal.ir/browse.php?a_id=281\&slc_lang=fa\&sid=1\&ftxt=1

[3] Rajabi, M., Roostai, S.H. and Maghami Moghim, G.H.R. (2006) Analysis of Neo Tectonic Activities on the Southern Slopes of Aladagh Mountains in North Eastern Iran. Geography and Development Iranian Journal, 8, 177-191. http://www.magiran.com/view.asp?Type=pdf\&ID=410964\&l=fa

[4] Ghanbari, E. (1997) Earthquakes Analysis in Relation to Active Faults in Azerbaijan. Geographic Space, Faculty of Humanities and Social Sciences, Tabriz University, No. 1-4.

[5] Madadi, A., Rezayi Moghaddam, M.H. and Rajayi, A. (2004) Analysis of Tectonic Activities by Using Geomorphology Methods in the Northwest Slopes in Talesh (Baghroo Dagh). Journal of Geographic Studies, 48, 123-138. http://www.sid.ir/fa/VEWSSID/J_pdf/51913834808.pdf

[6] Roostai, S.H. and Nayyeri, H. (2011) Quantitative Analysis of Lithology and Tectonic Influence in the Longitudinal Profile River, Case Study: Mahabad Basin. Geography and Development Iranian Journal, 24, 137-153. http://gdij.usb.ac.ir/pdf_534_97493174b3a5996f886242009d69a891.html

[7] Bull, W.B. (1984) Tectonic Geomorphology. Journal of Geological Education, 32, 310-324.

[8] Keller, E.A., Larry, G. and Tierney, T.E. (1999) Geomorphic Criteria to Determine Direction of Latera Propagation of Reverse Faulthing and Folding. Geology, 6, 515-518. http://activetectonics.asu.edu/ActiveFaultingSeminar/Papers/Keller\%20etal_1999.pdf

[9] Jamieson, S.S.R., Sinalair, H.D., Kirestein, L.A. and Purves, R.S. (2004) Tectonic Forcing of Longitudinal Valleys in the Himalaya, Morphometrical Analysis of the Ladakh Batholith, North India. Geomorphology, 58, 49-65. http://www.geosciences.ed.ac.uk/homes/sinclair/Jamieson.pdf

[10] Singh, T. and Jain, V. (2009) Tectonic Constraints on Watershed Development on Frontal Ridges: Mohand Ridge, NW Himalaya, India. Geomorphology, 106, 231-241. http://www.sciencedirect.com/science/article/pii/S0169555X0800490X http://dx.doi.org/10.1016/j.geomorph.2008.11.001

[11] Reyaz Ahmad, D., Shakil Ahmad, R., Rakesh, C. and Ishtiaq, A.(2014) Tectono-Geomorphic Study of the Karewa Basin of Kashmir Valley. Journal of Asian Earth Sciences, 92, 143-156. http://www.sciencedirect.com/science/article/pii/S1367912014002612

[12] Dehbozorgi, M., Pourkermani, M., Arian, M., Matkan, A.A., Motamedi, H. and Hosseiniasl, A. (2010) Quantitative Analysis of Relative Tectonic Activity in the Sarvestan Area, Central Zagros, Iran. Geomorphology, 121, 1-13. 
http://dx.doi.org/10.1016/j.geomorph.2010.05.002

[13] Hamdouni, R., Irigaray, C., Fernandez, T., Chacón, J. and Keller, E.A. (2007) Assessment of Relative Active Tectonics, Southwest Border of Sierra Nevada (Southern Spain). Geomorphology, 96, 150-173. http://dx.doi.org/10.1016/j.geomorph.2007.08.004

[14] Keller, E.A. and Nicholas, P. (1996) Active Tectonic, Earthquickes, Uplift and Landscape. 2nd Edition, Prentice Hall, Upper Saddle River, 362 p.

[15] Ritter, D.F., Kochel, R.C. and Miller, J.R. (1995) Process Geomorphology WBC/Mc Graw-Hill, Boston, 545 p.

[16] Hironi, K. (1991) Land Use Planning and Geomorphology: A Study of Sawai Madhopur. Concept Publishing Company, 187 p. http://www.conceptpub.com/servlet/Getbiblio?bno=00000267

[17] Bull, W.B. and McFadden, L.D. (1977) Tectonic Geomorphology North and South of the Garlock Fault, California. In: Doehring, D.O., Ed., Geomorphology in Arid Regions: A Proceedings Volume of the 8th Annual Geomorphology Symposium, State University of New York, Binghamton, 23-24 September 1977, 115-138.

[18] Davoodi, E., Shabaneian, N. and Davoodeian Dehkordi, A.R. (2013) Morphotectonic Characteristics Assessment in Zayandeh Rood River of North Eastern Chaharmahal and Bakhtiari Province. Journal of Advanced Applied Geology, 9, 10-19. http://aag.scu.ac.ir/article_10863_768a7a5bf086431b805407f33502191d.pdf

[19] Jabbari, N., Servati, M.R. and Hosein zadeh, M.M. (2012) The Study of Active Morphotectonic in Hesarak Basin (Northwest of Tehran) by Using Morphometric Indexes. Quantitative Geomorphological Researches, 2, 17-34. http://www.geomorphologyjournal.ir/browse.php?a id=44\&slc lang=fa\&sid=1\&ftxt=1

[20] Burbank, D.W. and Anderson, R.S. (2001) Tectonic Geomorphology. Blackwell Scientific, Oxford, 274 p.

\section{Submit or recommend next manuscript to SCIRP and we will provide best service for you:}

Accepting pre-submission inquiries through Email, Facebook, Linkedin, Twitter, etc

A wide selection of journals (inclusive of 9 subjects, more than 200 journals)

Providing a 24-hour high-quality service

User-friendly online submission system

Fair and swift peer-review system

Efficient typesetting and proofreading procedure

Display of the result of downloads and visits, as well as the number of cited articles

Maximum dissemination of your research work

Submit your manuscript at: http://papersubmission.scirp.org/ 